\title{
Effect of Stryphnodendron adstringens (Mart.) Coville extract in aerobic and
}

\section{anaerobic microorganisms and mammalian cells}

\author{
Efeito do extrato de Stryphnodendron adstringens (Mart.) Coville em microrganismos aeróbios e \\ anaeróbios e células de mamíferos \\ Efecto del extracto de Stryphnodendron adstringens (Mart.) Coville en microorganismos aeróbicos y
} anaeróbicos y células de mamíferos

Fábia Lugli Sper

ORCID: https://orcid.org/0000-0002-9708-046X São Paulo State University, Brazil

E-mail: fabiafarma@hotmail.com

Isabela Amêndola

ORCID: https://orcid.org/0000-0002-0010-9757 São Paulo State University, Brazil

E-mail: isabelaamendola@hotmail.com

Lucas de Paula Ramos

ORCID: https://orcid.org/0000-0002-2682-2796 São Paulo State University, Brazil

E-mail: lucas93paula@hotmail.com.br

Juliana Guimarães dos Santos

ORCID: https://orcid.org/0000-0002-2531-2102 São Paulo State University, Brazil

E-mail: juliana_biol@yahoo.com.br

Eduardo Tavares de Freitas

ORCID: https://orcid.org/0000-0003-4901-8124

São Paulo State University, Brazil

E-mail: eduardotfreitas@live.com

Vanessa Marques Meccatti

ORCID: https://orcid.org/0000-0003-3297-2288 São Paulo State University, Brazil

E-mail: vanessameccatti@gmail.com

Laís Fernanda Ferreira Ferraz

ORCID: https://orcid.org/0000-0003-4486-6335 São Paulo State University, Brazil E-mail: lais.ferraz@unesp.br

Jonatas Rafael de Oliveira

ORCID: https://orcid.org/0000-0003-2398-6506

Anhembi Morumbi University, Brazil

E-mail: jroliveira16@hotmail.com

Mauro Pedrine Santamaria

ORCID: https://orcid.org/0000-0001-9468-0729 São Paulo State University, Brazil

E-mail: mauro.santamaria@unesp.br

Maria Cristina Marcucci Ribeiro

ORCID: https://orcid.org/0000-0002-8065-5618 São Paulo State University, Brazil

E-mail: cris.marcucci@yahoo.com.br

Luciane Dias de Oliveira

ORCID: https://orcid.org/0000-0001-9956-7768

São Paulo State University, Brazil

E-mail: luciane.oliveira@unesp.br

\begin{abstract}
Stryphnodendron adstringens (Mart.) Coville is a medicinal plant known for its anti-inflammatory and antimicrobial properties. This study evaluated some biological activities of extract from S. adstringens. Antimicrobial activity was checked in planktonic cultures and monomicrobial biofilms on aerobic, and anaerobic dental microorganisms. Analyzes of cytotoxicity using MTT assay, and genotoxicity by micronucleus test were performed in human keratinocytes (HACAT), murine macrophages (RAW 264.7), and murine fibroblasts (L929). The anti-inflammatory
\end{abstract}


effect was checked in RAW 264.7 stimulated by lipopolysaccharide (LPS) from Escherichia coli, and treated with the plant extract. The levels of cytokines, and nitric oxide (NO) were measured by ELISA, and Griess method, respectively. Data were analyzed by ANOVA, followed by Tukey's, or Kruskal-Wallis, and Dunns tests $(P \leq 0.05)$. Biofilms of anaerobic bacteria were very susceptible to the plant extract. Effective concentrations showed cell viability $>50 \%$, except $25 \mathrm{mg} / \mathrm{mL}$ for HACAT after $24 \mathrm{~h}$ of exposure. The extract of $S$. adstringens was not genotoxic for RAW 264.7. LPS associated with extract increased the production of all cytokines, except TNF- $\alpha$. However, the plant extract decreased the production of NO. In conclusion, the extract of S. adstringens affected biofilm of anaerobic bacteria using non-cytotoxic concentrations for RAW 264.7, L929, and HACAT cells.

Keywords: Antimicrobial; Anti-inflammatory; Bacteria anaerobic; Biofilms; Medicinal plant; Phytotherapy.

\begin{abstract}
Resumo
Stryphnodendron adstringens (Mart.) Coville é uma planta medicinal conhecida por suas propriedades antiinflamatórias e antimicrobianas. Este estudo avaliou algumas atividades biológicas do extrato de S. adstringens. A atividade antimicrobiana foi verificada em culturas planctônicas e biofilmes monomicrobianos em microrganismos aeróbios e anaeróbios de interesse odontológico. Análises de citotoxicidade utilizando ensaio de MTT e genotoxicidade por meio do teste de micronúcleo foram realizadas em queratinócitos humanos (HACAT), macrófagos murinos (RAW 264.7) e fibroblastos murinos (L929). O efeito anti-inflamatório foi verificado em RAW 264.7 estimulado por lipopolissacarídeo (LPS) de Escherichia coli e tratado com o extrato da planta. Os níveis de citocinas e óxido nítrico (NO) foram medidos por ELISA e método de Griess, respectivamente. Os dados foram analisados por ANOVA e teste de Tukey ou Kruskal-Wallis e teste de Dunns $(\mathrm{P} \leq 0,05)$. Os biofilmes de bactérias anaeróbias foram muito suscetíveis ao extrato da planta. As concentrações efetivas mostraram viabilidade celular > 50\%, exceto 25 $\mathrm{mg} / \mathrm{mL}$ para HACAT após 24 h de exposição. O extrato de $S$. adstringens não foi genotóxico para RAW 264.7. O LPS associado ao extrato aumentou a produção de todas as citocinas, exceto TNF- $\alpha$. No entanto, o extrato da planta diminuiu a produção de NO. Em conclusão, o extrato de $S$. adstringens afetou o biofilme de bactérias anaeróbias usando concentrações não citotóxicas para células RAW 264.7, L929, e HACAT.
\end{abstract}

Palavras-chave: Antimicrobiano; Anti-inflamatório; Bactéria anaeróbia; Biofilme; Fitoterapia; Planta medicinal.

\title{
Resumen
}

Stryphnodendron adstringens (Mart.) Coville es una planta medicinal conocida por sus propiedades antiinflamatorias y antimicrobianas. Este estudio evaluó algunas actividades biológicas del extracto de $S$. adstringens. La actividad antimicrobiana se verificó en cultivos planctónicos y biopelícula monomicrobianos en microorganismos aerobios y anaerobios de interés dental. Se realizaron análisis de citotoxicidad mediante ensayo MTT y genotoxicidad mediante ensayo de micronúcleos en queratinocitos humanos (HACAT), macrófagos murinos (RAW 264.7) y fibroblastos murinos (L929). El efecto antiinflamatorio se verificó en RAW 264.7 estimulado por lipopolisacárido (LPS) de Escherichia coli y tratado con el extracto vegetal. Los niveles de citocinas y óxido nítrico (NO) se midieron mediante ELISA y el método de Griess, respectivamente. Los datos se analizaron mediante ANOVA y prueba de Tukey o prueba de Kruskal-Wallis y Dunns $(\mathrm{P} \leq 0,05)$. Las biopelículas de bacterias anaerobias fueron muy susceptibles al extracto de la planta. Las concentraciones efectivas mostraron viabilidad celular> 50\%, excepto $25 \mathrm{mg} / \mathrm{mL}$ para HACAT después de 24 h de exposición. El extracto de $S$. adstringens no fue genotóxico para RAW 264.7. El LPS asociado con el extracto aumentó la producción de todas las citocinas, excepto TNF- $\alpha$. Sin embargo, el extracto de la planta disminuyó la producción de NO. En conclusión, el extracto de $S$. adstringens afectó el biopelícula de bacterias anaerobias utilizando concentraciones no citotóxicas para RAW 264.7, L929 y HACAT.

Palabras clave: Antiinflamatorio; Antimicrobiana; Bacterias anaerobias; Biopelícula; Fitoterapia; Planta medicinal.

\section{Introduction}

The search for new antimicrobial drugs has become increasingly important due, mainly, to the resistance that microorganisms develop after a while under the action of these drugs. The study of medicinal plants can be an excellent alternative because they have a rich constitution of active biomolecules. Stryphnodendron adstringens (Mart.) Coville is a medicinal plant rich in tannins belonging to the Fabaceae family. Native to southeastern and central-western Brazil, it produces fleshy, light-brown fruits with many seeds (Lorenzi H \& Matos FJA, 2002; Maroni BC, 2006). Empirically, S. adstringens has been used as an antiseptic and antimicrobial as well as for treatments of diabetes, inflammation, gastritis, liver disease, pain, diarrhea, and bleeding (Costa et al., 2013; De Santana et al., 2016). Scientifically, some studies demonstrate that the aqueous extract of S. adstringens has antioxidant and anticancer properties (da Silva Baldivia et al., 2018), antifungal, including action against fluconazole-resistant isolates (de Freitas et al., 2018), pronounced anti-inflammatory activity (Henriques et al., 2016), and antimicrobial action (Costa et al., 2010; Ferreira, Palmeira, Souza, Almeida, Figueiredo, Pequeno, Arruda, 2010). 
This fact is important because several oral diseases have a dysbiotic microbial biofilm as the main etiological factor. Biofilms are three-dimensional structures in which several species of microorganisms are surrounded by an extracellular matrix that hinders the action of the immune system and antimicrobial agents. The species that make up the oral biofilm change as the maturity of the structure increases and may also vary between individuals. (Karched et al., 2015; Pathan, 2017).

There are many species capable of forming biofilms, such as Candida albicans, a yeast that can also form germ tubes and has adhesion proteins (Ganguly \& Mitchell, 2011). It is the main species responsible for causing oral candidosis. It can grow in anaerobiosis, being able to contribute to periodontal and endodontic infections (Bernal-Treviño et al., 2018; Razina et al., 2017). Enterococcus faecalis is an optional anaerobic bacterium that can invade dentinal tubules, initiate biofilm, and is associated with secondary endodontic infections (Tennert, Fuhrmann, Wittmer, Karygianni, Altenburger, Pelz, 2014; Wilson et al., 2015). Pseudomonas aeruginosa is an opportunistic aerobic pathogen that causes different acute and chronic infections. One of the main causes of nosocomial infections, and also associated with persistent root canal infections (Crone et al., 2020; Pourhajibagher et al., 2017). Staphylococcus aureus, considered an important opportunistic nosocomial pathogen is an optional anaerobic bacterium that frequently colonizes the nostrils without causing problems (Mehraj J, Witte W, Akmatov MK, Layer $\mathrm{F}, 2016)$. Streptococcus mutans is an optional anaerobic microorganism prevalent in the caries process. Important in the biofilm initiation process, it is capable of synthesizing extracellular polymers (Krzyściak, Jurczak, Kościelniak, Bystrowska B, 2014).

Obligate anaerobic bacteria can also form a biofilm, such as Fusobacterium nucleatum, an important bacterium for the maturation of a biofilm, and also is correlated with cases of gingivitis and chronic periodontitis (Karched et al., 2015; Okuda et al., 2012). Parvimonas micra is an anaerobic. and proteolytic bacterium found in the gingival sulcus. Currently, the frequency of case reports in the literature correlating P. micra with spondylodiscitis (spinal infection) has been extremely high and some patients had a dental problem before spinal infection (Durovic et al., 2020; van Duijvenbode et al., 2018). Porphyromonas endodontalis is a pathogen isolated from periodontal pockets, periapical lesions, endodontic infections and biofilm on the back of the tongue of patients with chronic periodontitis. (Pérez-Chaparro et al., 2018; Rôças \& Siqueira, 2018). Porphyromonas gingivalis is considered the main etiologic agent of periodontal diseases (Bostanci \& Belibasakis, 2012; Tamai et al., 2011).

In addition, microorganisms can also generate significant inflammatory processes in their hosts, due to their presence in the organism or only their constituents, such as lipopolysaccharide (LPS) and lipoteichoic acid (LTA), for example. Oral infections caused by the microorganisms described above can cause acute or chronic inflammatory processes requiring pharmacological intervention to minimize additional tissue damage (Headland \& Norling, 2015). Also, to an active substance being effective, it needs to be safe. There are many tests to show how much an organism tolerates a substance. Among them, in vitro tests using cell, and tissue cultures preferably mammals. The cytotoxicity tests allow evaluating the biological response of cells to a particular substance, through specific aspects of metabolism, morphological, or even cell growth and viability. Genotoxicity tests demonstrate effects on DNA, gene mutations, and chromosomal aberrations. Some studies have shown that S. adstringens maintains cell viability when analyzed on mammalian cell culture (de Oliveira et al., 2013; Henriques et al., 2016; Ishida et al., 2006), and has a protective effect on cellular genetic material (Costa et al., 2010; Pellenz et al., 2018).

There is a lack of studies in the literature that evaluated the antimicrobial activity of $S$. adstringens extract on such microorganisms of dental interest, particularly on anaerobic bacteria. It is also scarce studies with analysis of cytotoxicity to find a concentration that is effective and without toxic effects and that can be applied in the dental clinic in the future.

The purpose of this study was evaluated the biological activities of extract from S. adstringens (Mart.) Coville, such as antimicrobial effect on planktonic culture, and biofilms of $C$. albicans, E. faecalis, $P$. aeruginosa, S. aureus, S. mutans, $F$. nucleatum, $P$. endodontalis, $P$. gingivalis, and P. micra; cytotoxicity and genotoxicity in mammalian cells (murine macrophages, murine fibroblasts, and human keratinocytes); and anti-inflammatory action in LPS-stimulated murine 
macrophages.

\section{Methodology}

\subsection{Extract}

The glycolic extract of S. adstringens (Mart.) Coville was prepared from the stem bark of the plant and obtained commercially at $200 \mathrm{mg} / \mathrm{mL}$ of propylene glycol (Mapric, São Paulo, Brazil).

\subsection{Microorganisms}

Reference strains from American Type Culture Collection (ATCC) were used such as C. albicans (ATCC 18804), E. faecalis (ATCC 4083), P. aeruginosa (ATCC 15442), S. aureus (ATCC 6538), S. mutans (ATCC 35688), F. nucleatum (ATCC 25586), P. endodontalis (ATCC 35406), P. gingivalis (ATCC 33277), and P. micra (ATCC 23195). The microorganisms were frozen at $-80{ }^{\circ} \mathrm{C}$, and activated in a specific culture medium according to the metabolic needs, being Yeast Nitrogen Base broth (YNB - Sigma-Aldrich, St. Louis, USA), for C. albicans, and Brain Heart Infusion broth (BHI Himedia), for aerobic bacteria. They were incubated at $37{ }^{\circ} \mathrm{C}$ for $24 \mathrm{~h}$, with $5 \% \mathrm{CO}_{2}$ for $S$. mutans. For anaerobic bacteria, Brucella broth (Acumedia, Michigan, USA) supplemented with 5\% sterile defibrinated sheep blood (Newprov, Pinhais-PR, Brazil), 1\% hemin (Sigma-Aldrich), and 1\% menadione (Sigma-Aldrich) was used. These bacteria were incubated in anaerobiosis with nitrogen $80.01 \%$, carbon dioxide 10.02\%, and hydrogen 9.97\%; (Whitley DG250 Workstation, West Yorkshire, UK) at $37^{\circ} \mathrm{C}$ for $48 \mathrm{~h}$.

\subsection{Antimicrobial activity in planktonic cultures}

The Minimum Inhibitory Concentration (MIC) was determined by the broth microdilution method, according to the Clinical and Laboratory Standards Institute (Clinical and Laboratory Standards Institute, 2002, 2003, 2007), as described in documents M27-A2 for yeasts, M7-A6 for aerobic microorganisms, and M11-A7 for anaerobic microorganisms.

The microorganisms were prepared in sterile saline solution $(\mathrm{NaCl} 0.9 \%)$ with turbidity adjusted to 0.5 of the McFarland scale, from a $24 \mathrm{~h}$ culture for aerobic microorganisms at $37{ }^{\circ} \mathrm{C}$. The anaerobic bacteria were grown in Brucella broth supplemented at $37^{\circ} \mathrm{C}$ for $48 \mathrm{~h}$, before preparation in saline solution. In 96 -well plates, $100 \mu \mathrm{L}$ of broth was added in 10 wells, and $100 \mu \mathrm{L}$ of the extract was added only in the first well of the microplate, from which a two-fold serial dilution was performed, totaling 10 different concentrations. For this, Mueller Hinton broth (Himedia) for bacteria, and RPMI 1640 medium (with glutamine, without bicarbonate and with red phenol indicator) (Himedia) buffered with 3 -(N-morpholino) propane sulfonicpropane sulfonic acid (MOPS - Sigma-Aldrich) at $\mathrm{pH}$ 7.0, for C. albicans were used. For aerobic bacteria and yeast, $100 \mu \mathrm{L}$ of inoculum was added to the wells and the microplates were incubated at $37^{\circ} \mathrm{C}$ for $24 \mathrm{~h}$. For anaerobic bacteria, 10 $\mu \mathrm{L}$ of standardized inoculum was added to the wells, and the microplates were incubated in anaerobiosis for $48 \mathrm{~h}$. The MIC was determined as the lowest concentration of extract capable of inhibiting microbial growth was observed with the naked eye.

To determine the Minimal Microbicide Concentration (MMC) of the plant extract on aerobic bacteria and yeast, the contents of the wells $(100 \mu \mathrm{L})$ of the MIC, as well as the adjacent wells were seeded on BHI agar for the bacteria, and Sabouraud-dextrose (Himedia) for yeast. After $48 \mathrm{~h}$ of incubation, MMC was determined on the plate with no colonial growth. Regarding the anaerobic bacteria, the well contents were homogenized and $20 \mu \mathrm{L}$ of each concentration were seeded in supplemented Brucella agar, and incubated under anaerobic condition for $48 \mathrm{~h}$. 


\subsection{Antimicrobial activity in monomicrobial biofilms}

Initially, the action of the plant extract was verified in monomicrobial biofilms of C. albicans, E. faecalis, $P$. aeruginosa, S. aureus, and S. mutans (De Oliveira et al., 2014). For biofilm formation, each microbial suspension was standardized at $10^{7}$ Colony-Forming Units per milliliter (CFU/mL) in saline and added to microtiter plates (200 $\mu \mathrm{L} /$ well). The microplates were incubated $\left(37^{\circ} \mathrm{C}\right)$ under agitation $(75 \mathrm{rpm})$ for $90 \mathrm{~min}$. The supernatant was discarded and culture medium was added, being YNB broth for C. albicans, and BHI broth for bacteria. Incubation $\left(37^{\circ} \mathrm{C}\right)$ was performed for $48 \mathrm{~h}$, with the replacement of the culture medium after $24 \mathrm{~h}$. The biofilms were exposed to the plant extract for $5 \mathrm{~min}$ or $24 \mathrm{~h}$, using effective concentrations. Sterile saline was used as a negative control. Ten replicates were performed in each experimental group.

Posteriorly, $200 \mu \mathrm{L}$ of MTT solution (3-(4,5-Dimethylthiazol-2-yl)-2.5-diphenyltetrazolium bromide) was added to the wells and the microplates were incubated at $37{ }^{\circ} \mathrm{C}$ for $1 \mathrm{~h}$ in the dark. Afterward, the MTT solution was removed and 200 $\mu \mathrm{L}$ of dimethylsulfoxide (DMSO - Sigma-Aldrich) was added to the wells. After incubation of $10 \mathrm{~min}$, the microplates were stirred for another $10 \mathrm{~min}$, and proceeded to readon a spectrophotometer (Biotek ELx808) at $570 \mathrm{~nm}$. The Optical Densities (OD) were converted into the viability percentage of the biofilm.

To evaluate the action of the plant extract on biofilms of F. nucleatum, P. micra, P. endodontalis, and P. gingivalis, $100 \mu \mathrm{L} /$ well of microbial suspension $\left(1.5 \times 10^{8} \mathrm{CFU} / \mathrm{mL}\right)$, and $100 \mu \mathrm{L} /$ well of supplemented Brucella broth were added in microplates. The plates were then incubated at $37{ }^{\circ} \mathrm{C}$ in anaerobiosis for seven days with medium replacement every $48 \mathrm{~h}$. After, the biofilms were exposed to the plant extract for $5 \mathrm{~min}$ or $24 \mathrm{~h}$. Supplemented Brucella broth and $0.1 \%$ chlorhexidine were used as controls. These solutions were discarded, the biofilms were washed with sterile saline and disintegrated with an ultrasonic homogenizer (Sonoplus HD 2200 - Bandelin Electronic GmbH \& Co. KG, Berlin, Germany), with 25\% energy for $30 \mathrm{~s}$. The suspension was diluted, and $20 \mu \mathrm{L}$ seeded on Brucella agar. After $48 \mathrm{~h}$ of incubation, colonies were counted and given their concentration in $\mathrm{CFU} / \mathrm{mL}$.

\subsection{Cell culture}

Murine macrophages (RAW 264.7) and human keratinocytes (HACAT) from the Cell Bank of Rio de Janeiro - Paul Ehrlich Scientific-Technical Association (APABCAM, Rio de Janeiro, Brazil), and murine fibroblasts (L929) from the Laboratory of Dynamics of Cellular Compartments from the Vale do Paraíba University (UNIVAP, São José dos Campos, São Paulo, Brazil) were cultured in Dulbecco's modified Eagle's medium (DMEM-LGC Biotechnology, Cotia, Brazil) supplemented with 10\% fetal bovine serum (Invitrogen, New York, USA), 1\% penicillin-streptomycin (Gibco, Grand Island, New York, United States), and kept in cell culture flasks (TPP, Switzerland) at $37{ }^{\circ} \mathrm{C}$ with $5 \% \mathrm{CO}_{2}$ and atmospheric humidity. The culture medium was changed every $48 \mathrm{~h}$. After subconfluency, the cells were used in the tests. The Trypan blue exclusion test $(0.4 \%$, Sigma-Aldrich) was performed to count the cells.

\subsection{Cytotoxicity analysis}

In 96-well microplates (Kasvi), $200 \mu \mathrm{l}$ of DMEM containing $4 \times 10^{4}$ viable cells were added to the wells. After $24 \mathrm{~h}$ of incubation, $200 \mu \mathrm{L} /$ well of the extract were added on the cells at different concentrations, pure DMEM was used as control ( $n=8$ /group). The supernatants were discarded and cell viability checked by MTT assay (as mentioned before), after $4 \mathrm{~h}$ of incubation.

\subsection{Genotoxicity analysis}

The micronucleus (MN) test was performed according to the Organization for Economic Co-operation and Development (Organization for Economic Co-operation and Development (OECD)., 2014). 
For the test, $5 \times 10^{5}$ viable cells/well were grown in 24-well plates for $24 \mathrm{~h}$. The cells were then exposed at different extract concentrations diluted in DMEM, $5 \mu \mathrm{M}$ ethyl methanesulfonate (EMS), was used as a positive control, or pure DMEM was used as a negative control for $24 \mathrm{~h}$. Next, the cells were incubated with cytochalasin B (Sigma-Aldrich) at $6 \mu \mathrm{g} / \mathrm{mL}$ for $24 \mathrm{~h}$. Then, the cells were fixed with methanol for $10 \mathrm{~min}$ and stained with $300 \mathrm{nM}$ DAPI diluted in PBS for 10 min. Cells were washed with PBS and observed under fluorescence microscopy, where 2000 cells/well per concentration $(n=3)$ were evaluated. MN were identified as DNA structures contained in the cytoplasm separated from the main nucleus, surrounded by a nuclear membrane, and including an area smaller than $1 / 3$ of the area of the main nucleus. Cells with less than $5 \mathrm{MN}$ were counted.

\subsection{Anti-inflammatory activity}

In 24-well plates, RAW 264.7 were cultured at $5 \times 10^{5}$ cells/well for $24 \mathrm{~h}$. After incubation, culture medium with different concentrations of extract from S. adstringens was added. At the same time, LPS from E. coli (Sigma) at $1 \mu \mathrm{g} / \mathrm{mL}$ was added to the wells. Groups without LPS were used as controls. After $24 \mathrm{~h}$ of incubation, the supernatants were collected and stored at $-20{ }^{\circ} \mathrm{C}$ for quantification of pro-inflammatory (TNF- $\alpha$, IL-1 $\beta$, IL-6, and IL-17), and anti-inflammatory (IL-10) cytokines by ELISA ( $R$ \& D Systems, Minneapolis, United States of America) according to the manufacturer's instructions.

\subsection{Production of nitric oxide (NO)}

The production of NO by RAW 24.7 was determined by the concentration of nitrite detected by the Griess reagent. For this, $100 \mu \mathrm{L}$ of cell supernatant, and $100 \mu \mathrm{L}$ of Griess reagent were added in 96 -well plates. After $10 \mathrm{~min}$, the absorbance of the wells was read on a microplate spectrophotometer at $570 \mathrm{~nm}$. To calculate the nitrite concentration, a standard curve of nitrite from 23 to $0.72 \mathrm{pg} / \mathrm{mL}$ was used.

\subsection{Statistical analysis}

The results were presented in mean values ( \pm standard deviation) and data distribution was assessed by Shapiro-Wilk. The data that presented normal distribution were analyzed by ANOVA complemented by Tukey's test, with significance of 5\% $(P \leq 0.05)$. The results that did not present normal distribution were analyzed by Kruskal-Wallis and Dunns tests $(P \leq 0.05)$.

\section{Results}

\subsection{Antimicrobial activity}

Regarding the antimicrobial activity of extract from S. adstringens on aerobic microorganisms, it was possible to observe action only on P. aeruginosa. There was no growth inhibition for the other microorganisms. In the microdilution tests, the highest concentration analyzed was $50 \mathrm{mg} / \mathrm{mL}$ and in the tests of the antibiofilm action of the extract, higher concentrations $(50,100$, and $200 \mathrm{mg} / \mathrm{mL})$ were used, and only the biofilm of $P$. aeruginosa suffered a significative reduction, however, no statistical difference $(p>0.05)$ was found.

Regarding anaerobic microorganisms, it was not possible to determine the MIC due to the turbidity of extract from $S$. adstringens, and the color of the medium (data not shown). Our study showed an MMC of $50 \mathrm{mg} / \mathrm{mL}$ for $F$. nucleatum, and > $100 \mathrm{mg} / \mathrm{mL}$ for other species. Concerning monomicrobial biofilms from anaerobic bacteria, a significant susceptibility to the plant extract was verified, with a minimum reduction of 50\% (F. nucleatum, 5 min), as shown in Figure 1. 
Figure 1. Action of extract from S. adstringens (Mart.) Coville on anaerobic biofilms. Different letters indicate statistically different groups. Mean values \pm standard deviation of the reduction of biofilm mono species of A) Fusobacterium nucleatum, B) Porphyromonas endodontalis C) Porphyromonas gingivalis, and D) Parvimonas micra. CLX: chlorhexidine. $(n=8$. Khruskal-Wallis, Dunns test, $P \leq 0.05$ ).
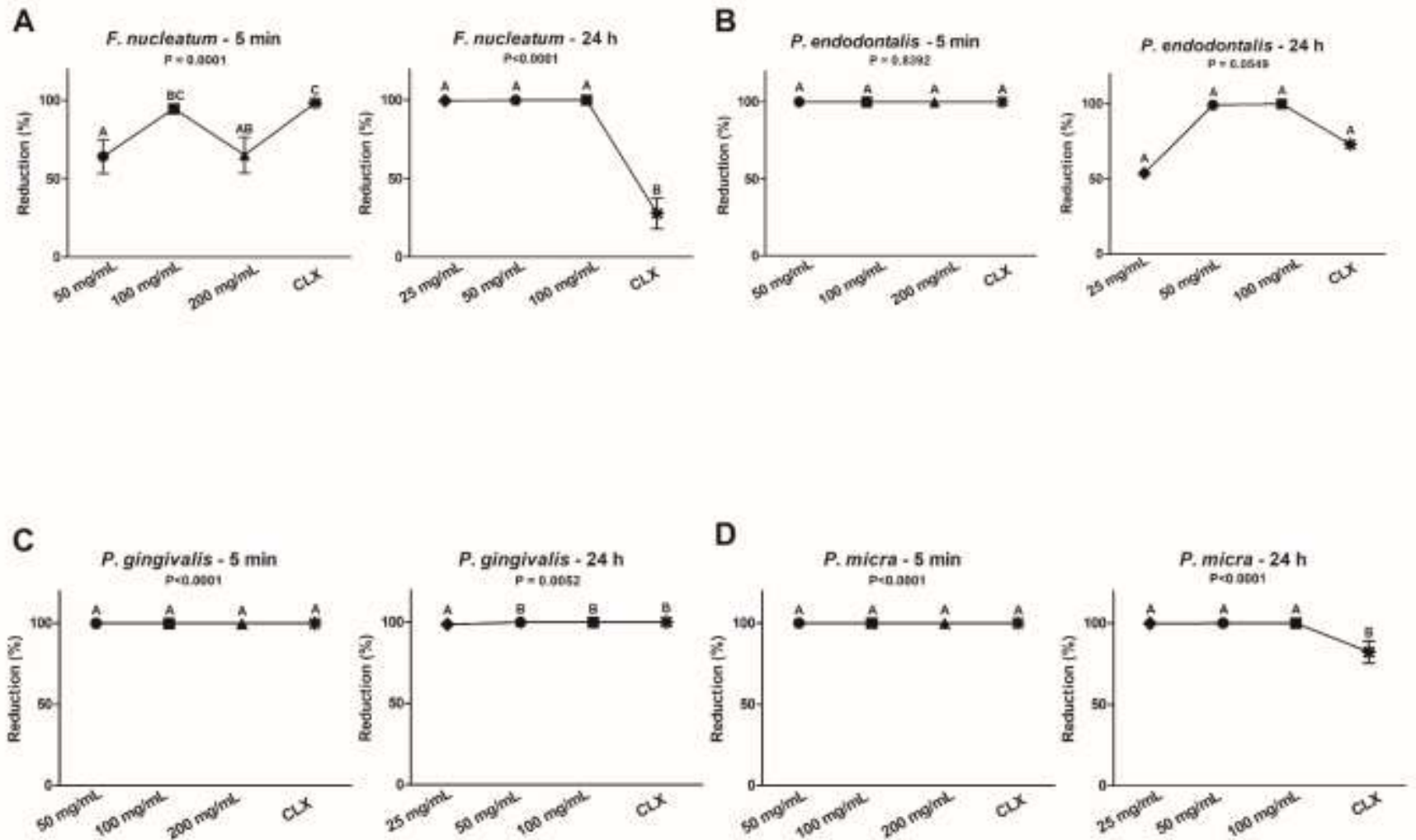

Source: Authors.

\subsection{Cytotoxicity}

Ten concentrations were evaluated of bark extract from S. adstringens in RAW 264.7, L929, and HACAT. Different responses were observed (Figure 2); however, the effective concentrations for anaerobic bacteria showed cell viability $>50 \%$ in mammalian cells, generally. 
Figure 2. Cytotoxicity of extract from $S$. adstringens (Mart.) Coville. Mean values \pm standard deviation of the extract cytotoxicity on A) Human keratinocytes (HACAT) for $5 \mathrm{~min}$, B) Keratinocytes (HACAT) for $24 \mathrm{~h}, \mathrm{C}$ ) Murine macrophages (RAW 264.7) for 5 min, D) Murine macrophages (RAW 264.7) for $24 \mathrm{~h}$, E) Murine fibroblasts (L929) for 5 min, and F) murine fibroblasts (L929) for $24 \mathrm{~h}$. ( $n=8$. ANOVA, Tukey's test, $P \leq 0.05$ ).

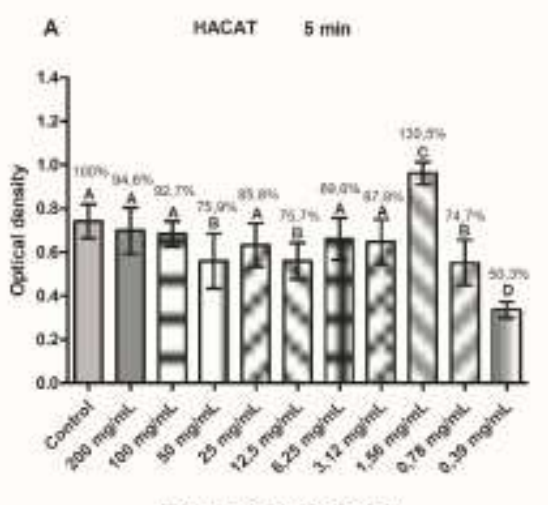

Extract concentration ingimly
tisis Foctertage of col vatery

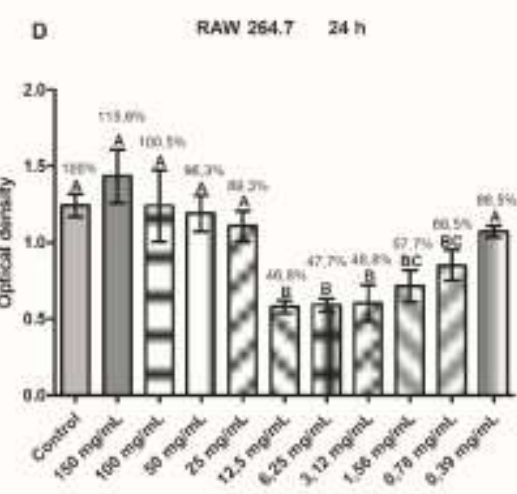

Eatract concentirnoen (mginc)
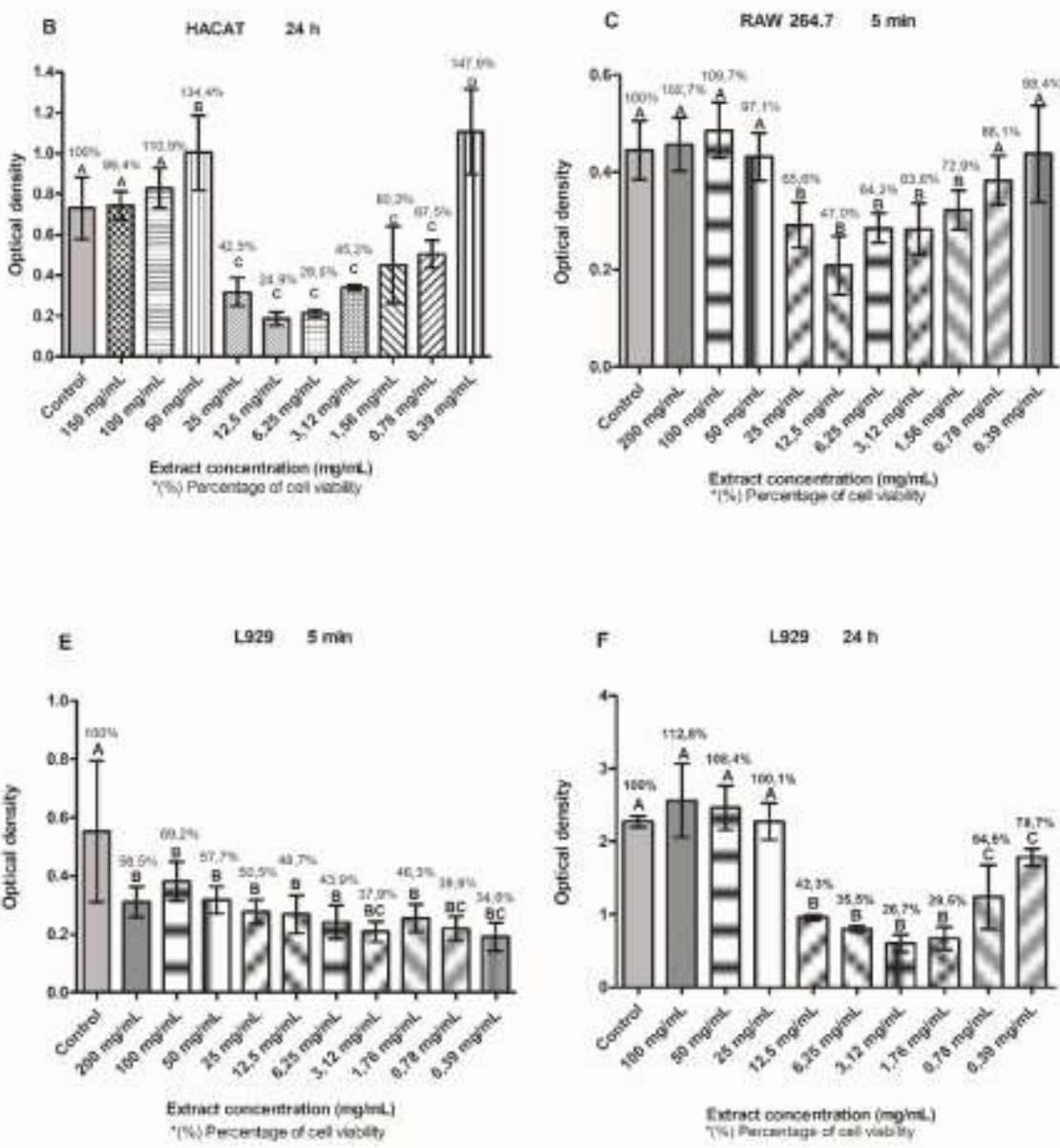

Source: Authors.

\subsection{Genotoxicity}

The genotoxicity of two concentrations $(50$ and $100 \mathrm{mg} / \mathrm{mL}$ ) of extract from $S$. adstringens was tested in HACAT, RAW 264.7, and L929 (Figure 3). These concentrations were not genotoxic for murine macrophages. At the concentration of $100 \mathrm{mg} / \mathrm{mL}$, the extract was not cytotoxic to murine fibroblasts. Human keratinocytes were less sensitive to the genotoxic agent used (EMS) and all treatments were statistically similar making the results inconclusive. 
Figure 3. Genotoxicity of S. adstringens (Mart.) Coville extract. Different letters indicate statistically different groups. Mean values \pm standard deviation of the extract genotoxicity on A) human keratinocytes (HACAT), B) murine macrophages (RAW 264.7) and C) murine fibroblasts (L929). C (-) = pure DMEM, C $(+)=$ EMS. Extract concentration $(\mathrm{mg} / \mathrm{mL})$. $(n=8$. ANOVA, Tukey's test, $P \leq 0.05)$. In the photos, micronuclei $(\mathrm{MN})$ are DNA fragments located around and close to the cell nucleus (indicated by white arrows), viewed by fluorescence microscopy and may have variable size but always smaller than the cell nucleus and varied amount, as shown in the photos aligned with each graph. Its presence characterizes DNA damage. The left, sequence of photos of MN in HACAT in the control groups, and with Barbatimão extract (Bar $50 \mathrm{mg} / \mathrm{mL}$ and $100 \mathrm{mg} / \mathrm{mL}$ ). In the middle, sequence of photos of MN in RAW 264.7 and to the right, sequence of photos of MN in L929.
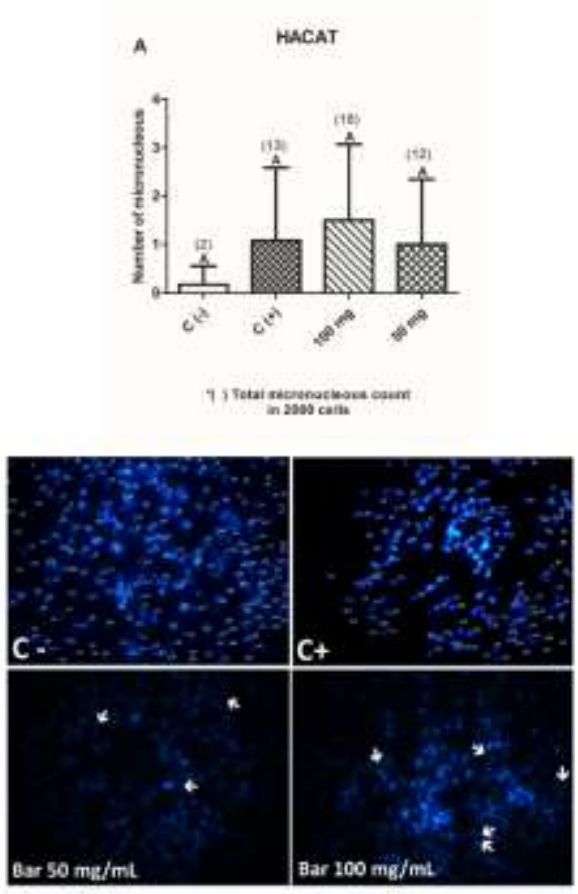
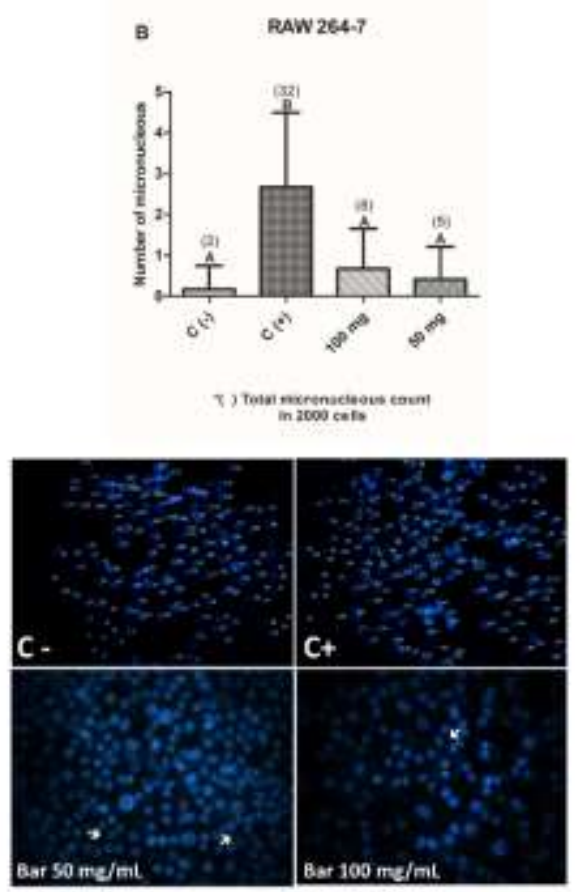
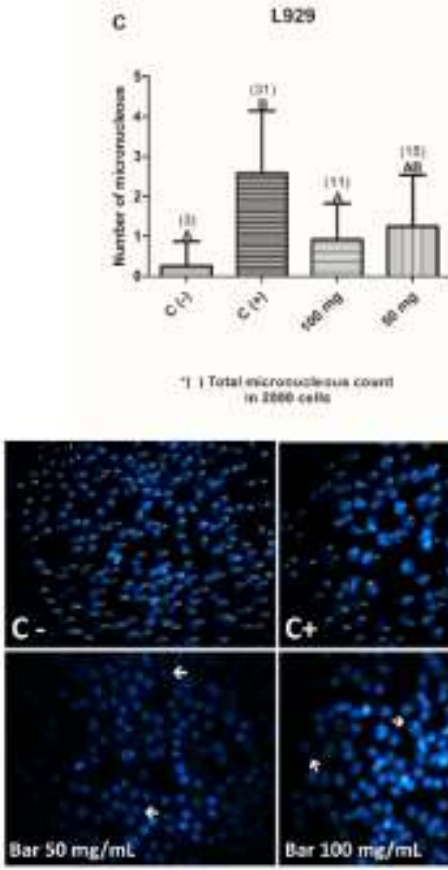

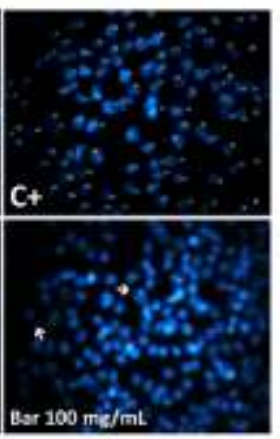

Source: Authors.

\subsection{Anti-inflammatory activity}

In the evaluation of anti-inflammatory activity, it was possible to observe that the extract only increased the release of IL-1 $\beta$ and IL-17 at $50 \mathrm{mg} / \mathrm{mL}$ in non-LPS-stimulated macrophages. On the other hand, when the extract was associated with LPS stimulation, all the cytokines were increased, except TNF- $\alpha$, which was reduced in the concentration of $100 \mathrm{mg} / \mathrm{mL}$ but was similar to the positive control with $50 \mathrm{mg} / \mathrm{mL}$ (Figure 4). 
Figure 4. Action of Stryphnodendron adstringens (Mart.) Coville extract on the production of cytokines in murine macrophages (RAW 264.7). Different letters indicate statistically different groups. Mean values \pm standard deviation (pg/mL) of: A) IL-1 $\beta$, B) IL-6, C) IL-17, D) TNF- $\alpha$ e E) IL-10. C (-) = DMEM, C (+) = DMEM + LPS. (n= 8. ANOVA, Tukey's test, $P \leq 0.05)$.

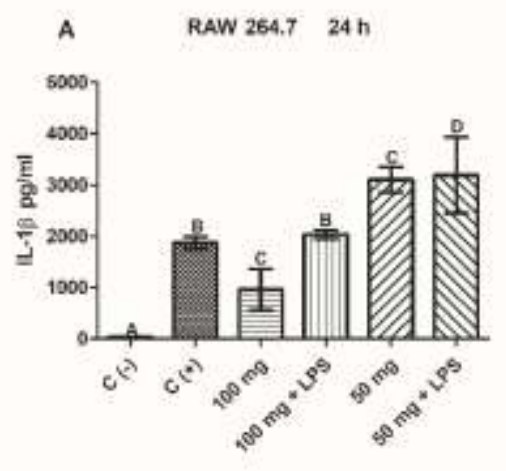

Extrat concostration ingint:

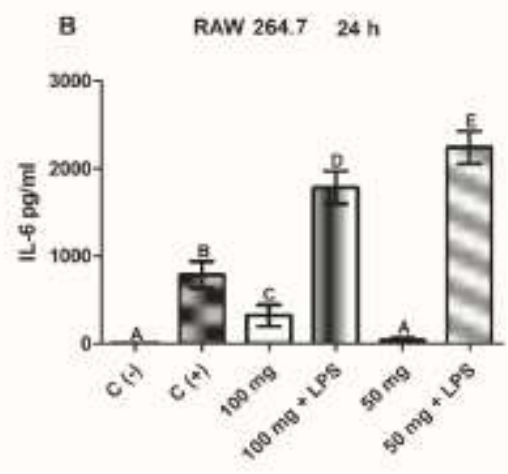

Extract concentratian (ingire)

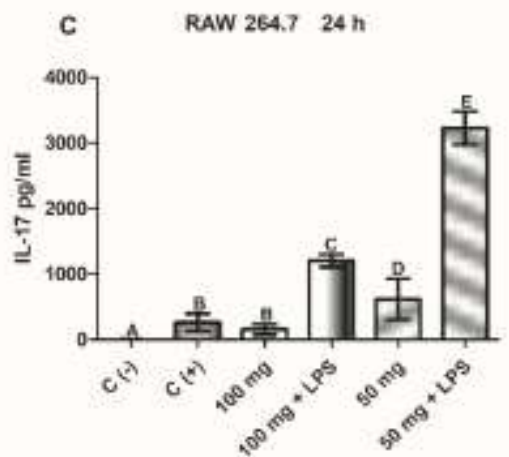

Extract concantration (ingimL)

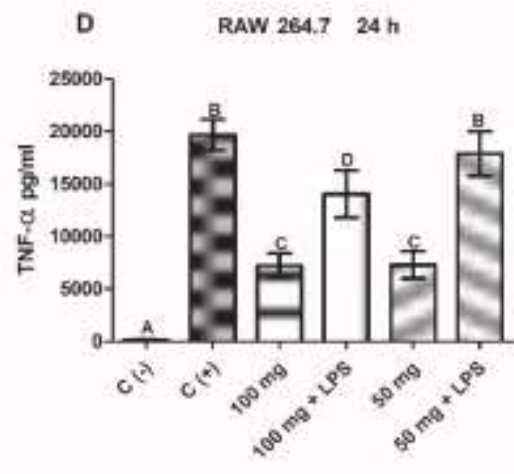

Exuract concentation imgiml:

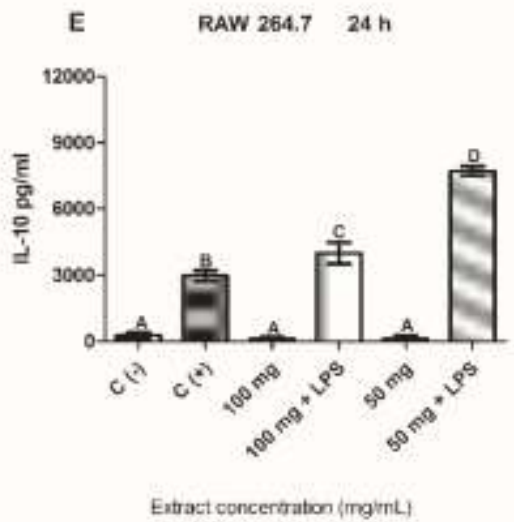

Extract concereration (meiml)

Source: Authors.

\subsection{Production of NO}

The ability to inhibit the production of nitric oxide (NO) can contribute to the performance of the extract's antiinflammatory activity. The average values of nitrite $(\mathrm{pg} / \mathrm{mL})$, referring to the production of nitric oxide, obtained in each experimental group, in comparison with the control groups, are shown in Table 1. It was observed that in the groups treated with $S$. adstringens extract at $25 \mathrm{mg} / \mathrm{mL}$ (+ LPS), and $50 \mathrm{mg} / \mathrm{mL}$ (+ LPS) there was a significant reduction in the production of NO in relation to the group with LPS and without extract $(P<0.05)$. The groups treated with $S$. adstringens extract at 100 $\mathrm{mg} / \mathrm{mL}$ group (+ LPS) promoted higher levels of nitric oxide, which was similar to the positive control (LPS without extract). The negative control group (without LPS stimulation) had the lowest level of nitrite, being statistically different from the other groups $(P<0.05)$. 
Table 1. Level of nitrite ( $\mathrm{pg} / \mathrm{ml})$ obtained in experimental and control groups

\begin{tabular}{lc}
\hline Experimental groups & Level of nitrite $(\mathrm{pg} / \mathrm{mL})$ \\
\hline Negative control & $0.124 \pm 0.082^{\mathrm{A}}$ \\
Positive control (LPS) & $2.351 \pm 0.806^{\mathrm{B}}$ \\
S. adstringens $100 \mathrm{mg} / \mathrm{mL}+$ LPS & $2.872 \pm 0.000^{\mathrm{B}}$ \\
S. adstringens $50 \mathrm{mg} / \mathrm{mL}+$ LPS & $1.227 \pm 0.659^{\mathrm{C}}$ \\
S. adstringens $25 \mathrm{mg} / \mathrm{mL}+$ LPS & $0.962 \pm 0.274^{\mathrm{C}}$ \\
\hline
\end{tabular}

Different letters indicate statistically different groups. (ANOVA, Tukey's test, $P \leq 0.05$ ). Source: Authors.

\section{Discussion}

In the present study, the plant extract was not able to inhibit the growth of the aerobic microorganisms analyzed, except $P$. aeruginosa. Likewise, only the monomicrobial biofilm of $P$. aeruginosa was significantly decreased. There are no reports in the literature regarding the antimicrobial activity of this plant extract on E. faecalis, and P. aeruginosa regarding the antibiofilm action on the other strains tested in the present study.

To check the antimicrobial action of some fractions from extract of $S$. adstringens, the agar diffusion test, and microdilution were used on ATCC strains of C. albicans, S. mutans, S. aureus, and Aggregatibacter actinomycetemcomitans. The vegetable compound showed antimicrobial activity at different levels for all strains tested (Pereira et al., 2011). A gel formulation produced from fractions of samples of the stem and bark of S. adstringens (Mart.) Coville was able to promote antifungal effect on clinical strains of Candida in addition to presenting anti-inflammatory action. The antimicrobial effect of the formulation was evaluated on planktonic cultures and biofilm. It was identified that the tannins present in the fractions of the $S$. adstringens extract were responsible for the antibiofilm action (de Freitas et al., 2018).

Regarding the antimicrobial action of other plant extracts of such species studied, Rosmarinus officinalis L., and Thymus vulgaris $\mathrm{L}$. extracts acted efficiently on planktonic cultures, and monomicrobial biofilms of C. albicans, S. aureus, E. faecalis, S. mutans, and P. aeruginosa (de Oliveira et al., 2017; Oliveira et al., 2017).

With respect to anaerobic microorganisms, there are not yet studies in the literature reporting the antimicrobial activity of $S$. adstringens extract on anaerobic microorganisms here evaluated. On the other hand, different extracts from Mediterranean plants, such as Cistus creticus L., Cistus monspeliensis L., Origanum vulgare L., Rosmarinus officinalis L., Thymus longicaulis $\mathrm{C}$., and Salvia sclarea $\mathrm{L}$. have shown antimicrobial potential for several microorganisms, including $C$. albicans, S. aureus, S. mutans, E. faecalis, P. gingivalis, F. nucleatum, and P. micra among clinical isolates and ATCC strains. All the evaluated extracts effectively inhibited the obligate anaerobic bacteria (Hickl et al., 2018).

Also, the inhibitory potential of Olea europaea extract has been found in periodontal pathogens, such as $P$. gingivalis, F. nucleatum, and Prevotella intermedia (Karygianni et al., 2014). Some compounds from O. europaea, and Pistacia lentiscus have also demonstrated antimicrobial action on several oral pathogens. These molecules were highly effective against Streptococci spp., P. gingivalis, F. nucleatum, and P. micra. However, the extracts were ineffective for $P$. intermedia (Karygianni et al., 2019). Melaleuca alternifolia oil has also shown antimicrobial activity against $P$. gingivalis and $P$. endodontalis, using subinhibitory concentrations (Graziano et al., 2016). The potential to reduce substances related to halitosis has also been shown by several plant extracts, such as Caesalpinia ferrea Mart., Cinnamomum cassia B., Mallow sylvestris L., Punica granatum L., Rosmarinus officinalis L., Aeolanthus suaveolens (Als.) Spreng., Sysygium aromaticum L., and 
Tamarindus indica L., since these natural products have acted against microorganisms that produce volatile sulfur compounds, such as F. nucleatum, P. gingivalis, $P$. intermedia, and P. micra (Veloso et al., 2020).

Concerning anaerobic biofilm studies, 24 h contact to the $S$. adstringens extract on biofilms of $F$. nucleatum, and $P$. micra promoted a reduction of $100 \%$ at all analyzed concentrations, differing statistically from the chlorhexidine $0.12 \%$ that promoted a percentage low reduction. This substance is considered a gold standard anti-plaque agent and in the present study, the extract of $S$. adstringens acted better than chlorhexidine. Regarding $5 \mathrm{~min}$ contact to the $S$. adstringens extract, all evaluated concentrations acted similarly to $0.12 \%$ chlorhexidine in the reduction $P$. gingivalis, $P$. endodontalis, and $P$. micra biofilms, presenting a high percentage of reduction. The results presented here indicate that S. adstringens has strong antibiofilm activity in all tested anaerobic strains. There are not yet studies in the literature that have reported the effect of $S$. adstringens extract in the anaerobic pathogens evaluated in this study. However, chemical constituents of Pinus elliottii oleoresin have presented antimicrobial action on some anaerobic oral pathogens including $P$. gingivalis and $F$. nucleatum, both planktonic culture and biofilms. P. elliottii oleoresin and its main compound exhibited antibacterial activity and the acid prevented all the evaluated bacteria from forming biofilm (Caetano da Silva et al., 2014). Plant oils from Leptospermum scoparium and Melaleuca alternifolia inhibited the adhesion of $P$. gingivalis and $S$. mutans suggesting that phytochemical oils suppress biofilm formation (Takarada et al., 2004). There are no studies in the literature on the antibiofilm action of natural compounds on P. micra and P. endodontalis. Currently, there has been a considerable increase in the studies about systemic infections related to P. micra such as spondylodiscitis (infection in the spine). A case series reported in 2020 showed that of the six cases, five P. micra is the only pathogen isolated from spine infection (Durovic et al., 2020). Analyzing alternative therapeutic agents that are effective against infections caused by these microorganisms is very important and in the present study, the plant extract was very efficient against this pathogen.

Regarding cytotoxicity analyzes, in the present study, the effective concentrations for anaerobic bacteria showed cell viability $>50 \%$. tannins from the S. adstringens (Mart.) Coville bark were not very cytotoxic for murine macrophage (J774G8) cells and green monkey kidney cells (Vero), but the cutoff point of this study was 50\% (Ishida et al., 2006). The extract of the bark of S. adstringens (Mart.) Coville was tested on RAW 264.7, and was found cell viability of $65 \%$ using a concentration of $12.5 \mathrm{mg} / \mathrm{mL}$ and $>70 \%$ for concentrations of 50, 25, and $3.13 \mathrm{mg} / \mathrm{mL}$ (de Oliveira et al., 2013). Another study with an extract from the S. adstringens bark demonstrated cell viability > 90\% for the human monocytes (THP-1) cells (ATCC TIB-202) (Henriques et al., 2016). The cytotoxic effect of the extract from leaves S. adstringens (Mart.) Coville was tested in two human breast cancer cell lines (MCF-7 and MDA-MB-435), and also on the primary culture of rat marrow cells. The study concluded that the extract was cytotoxic with a 50\% cutoff point (Sabino et al., 2018).

Concerning genotoxicity analyzes, in the present study, the highest concentrations tested were not genotoxic for RAW 264.7 and L929. The effect of the S. adstringens hydroalcoholic extract has also been evaluated for cell viability, DNA damage, and apoptosis induction in keratinocytes (HaCaT), and fibroblast (HFF-1) cell lines. The results have suggested that the extract may have a genoprotective and anti-apoptotic effects for human keratinocytes and fibroblasts (Pellenz et al., 2018). The S. adstringens ethanolic extract was used at 50,100, and $200 \mathrm{mg} / \mathrm{kg}$, and was found that the two higher concentrations reduced the genotoxicity caused by mitomycin C (Silva-de-Andrade et al., 2006). Another study demonstrated that the proanthocyanidins rich fraction of the stem bark of S. adstringens was not genotoxic at 750, 1500, and 2000 mg/kg and also conferred protection to the cellular genetic material of the cyclophosphamide-treated groups at $750 \mathrm{mg} / \mathrm{mL}(\mathrm{Costa}$ et al., 2010). Besides, was verified the antigenotoxic activity of aqueous and ethanolic extracts of S. adstringens leaves on genotoxicity caused by cyclophosphamide (Filho et al., 2011). On the other hand, the aqueous solution of S. adstringens was genotoxic at $30 \mathrm{mg} / \mathrm{mL}$ for erythrocytes of mice treated with mitomycin C (Chaves DS, Lemes SR, Montes de Sousa MA, da Rocha Souza 
EGA, Alves de Araújo L, Mrué F, 2017). The plant product showed relative genotoxicity when evaluated by SOS-Inductest (Vilar et al., 2010).

About anti-inflammatory activity, it has already been reported that there is the increased IL-1 $\beta$ in RAW 264.7 treated with $50 \mathrm{mg} / \mathrm{mL}$ of extract from S. adstringens, but in this study, the same concentration reduced the release of TNF- $\alpha$ which did not occur in the present study (de Oliveira et al., 2013). Another study demonstrated that there is a reduction of TNF- $\alpha$ using human monocytes (THP-1) and the extract of S. adstringens (Mart.) Coville at concentrations of 250, 125, and 62.5 $\mu \mathrm{g} / \mathrm{mL}$ (Henriques et al., 2016). It was also observed that the extracts did not increase the production of TNF- $\alpha$ in cells not stimulated with LPS. No studies on the action of S. adstringens on other cytokines have been found in the literature.

To the production of NO, there are no reports in the literature on the action of S. adstringens for the production of NO. This shows the importance of the current study because we found that $S$. adstringens may be a potential NO inhibitor. Some natural extracts and their phytochemicals, such as Apios americana (Seo et al., 2018), Inula Japonica (Jin et al., 2016), and the propolis ethanolic extract (Onbas et al., 2016) have demonstrated potent NO inhibitor effect when evaluated on LPS-stimulated RAW 264.7 cells.

\section{Conclusion}

In conclusion, extract of $S$. adstringens (Mart.) Coville was effective for monomicrobial biofilms of anaerobic bacteria at low non-cytotoxic concentrations for RAW 264.7, L929, and HACAT cells. This study has elucidated important biological activities of $S$. adstringens extract however, for further analysis, the authors believe to be necessary additional in vitro trials and the near future, start in vivo analyzes in invertebrate models that allow to obtain preliminary results such as the toxicity of the plant extract in vivo.

\section{List of abbreviations}

ATCC: American Type Culture Collection

BHI: Brain Heart Infusion broth

CFU/mL: Colony-forming units per milliliter

DMEM: Dulbecco's modified Eagle's medium

DMSO: Dimethylsulfoxide

EMS: Ethyl methanesulfanate

HACAT: Human keratinocytes cells

IL-10: Interleukin 10

IL-1 $\beta$ : Interleukin 1 beta

IL-6: Interleukin 6

J774G8: Murine macrophage cells

L929: Murine fibroblasts cells

LPS: Lipopolysaccharide

LTA: Lipoteichoic acid

MCF-7: Breast adenocarcinoma

MDA-MB-435: Melanoma cell line

MIC: Minimum Inhibitory Concentration

MMC: Minimal Microbicide Concentration 
$\mathrm{MN}$ : Micronucleus

MTT: 3-(4.5-Dimethylthiazol-2-yl)-2.5-diphenyltetrazolium bromide)

$\mathrm{NaCl}: 0.9 \%$ Sterile saline solution

NO: Nitric Oxide

OD: Optical Densities

RAW 264.7: Murine macrophages cells

THP-1: Human monocytes cells

TNF- $\alpha$ : Tumor necrosis factor alpha

Vero: Green monkey kidney cells

YNB: Yeast Nitrogen Base broth

\section{Declarations}

\section{Competing interests}

The authors declare that they have no competing interests.

\section{Funding}

This work was supported by the Fundação de Amparo à Pesquisa do Estado de São Paulo (FAPESP) grant number 15/08776-3.

\section{Authors' contributions}

FLS: conception, design of the experiments, interpretation of data and drafting of the manuscript. IA: design of the experiments and interpretation of data. LPR: analysis and interpretation of data. JGS: analysis and interpretation of data. ETF: design of the experiments. VMM: drafting of the manuscript. LFFF: design of the experiments, interpretation of data and drafting of the manuscript. JRO: review of the manuscript and prepared the linguistic correction of the manuscript. MPS: critical analysis, review of the manuscript and prepared the linguistic correction of the manuscript. MCMR: critical analysis and review of the manuscript. LDO: conception, analysis and interpretation of data, critical analysis and review of the manuscript. All authors read and approved the final manuscript.

\section{Acknowledgements}

FAPESP scholarship: 2015/17927-5.

Conselho Nacional de Desenvolvimento Científico e Tecnológico (CNPq): 307396/2018-5.

\section{References}

Bernal-Treviño, A., González-Amaro, A. M., Méndez González, V., \& Pozos-Guillen, A. (2018). Frecuencia de Candida en conductos radiculares de dientes con infección endodóntica primaria y persistente. Revista Iberoamericana de Micología, 35(2), 78-82. https://doi.org/10.1016/J.RIAM.2017.09.004

Bostanci, N., \& Belibasakis, G. N. (2012). Porphyromonas gingivalis: An invasive and evasive opportunistic oral pathogen. In FEMS Microbiology Letters (Vol. 333, Issue 1, pp. 1-9). https://doi.org/10.1111/j.1574-6968.2012.02579.x

Caetano da Silva, S. D., Mendes de Souza, M. G., Cardoso, M. J. O., da Silva Moraes, T., Ambrósio, S. R., Veneziani, R. C. S., \& Martins, C. H. G. (2014). Antibacterial activity of Pinus elliottii against anaerobic bacteria present in primary endodontic infections. Anaerobe, 30, 146-152. https://doi.org/10.1016/j.anaerobe.2014.09.013

Chaves, D. S., Lemes, S. R., Montes de Sousa, M. A., da Rocha Souza, E. G. A., Alves de Araújo, .L, Mrué, F. de M.-R. P. (2017). Evaluation of the genotoxic and antigenotoxic activity of Barbatimão (Stryphnodendron adstringens). EVS, 44, 56-61. 
Clinical and Laboratory Standards Institute. (2002). Reference Method for Dilution Tests in Broth for Determining the Sensitivity of Yeasts to Antifungal Therapy, Approved standard (p. CLSI document M27-A2. 2nd ed. USA.).

Clinical and Laboratory Standards Institute. (2003). Methodology for Sensitivity Tests to Antimicrobial Agents by Dilution for Aerobic Growth Bacteria. Approved standard (p. CLSI document M7-A6. 6th ed. USA.).

Clinical and Laboratory Standards Institute. (2007). Methods for antimicrobial susceptibility testing of anaerobic bacteria. Approved standard (p. CLSI document M11-A7. 7th ed. USA.).

Costa, M. A., Ishida, K., Kaplum, V., Koslyk, É. D. A., de Mello, J. C. P., Ueda-Nakamura, T., Filho, B. P. D., \& Nakamura, C. V. (2010). Safety evaluation of proanthocyanidin polymer-rich fraction obtained from stem bark of Stryphnodendron adstringens (BARBATIMO) for use as a pharmacological agent. Regulatory Toxicology and Pharmacology, 58(2), 330-335. https://doi.org/10.1016/j.yrtph.2010.07.006

Costa, M. A., Palazzo De Mello, J. C., Kaneshima, E. N., Ueda-Nakamura, T., Dias Filho, B. P., Audi, E. A., \& Nakamura, C. V. (2013). Acute and chronic toxicity of an aqueous fraction of the stem bark of stryphnodendron adstringens (Barbatimão) in rodents. Evidence-Based Complementary and Alternative Medicine, 2013. https://doi.org/10.1155/2013/841580

Crone, S., Vives-Flórez, M., Kvich, L., Saunders, A. M., Malone, M., Nicolaisen, M. H., Martínez-García, E., Rojas-Acosta, C., Catalina Gomez-Puerto, M., Calum, H., Whiteley, M., Kolter, R., \& Bjarnsholt, T. (2020). The environmental occurrence of Pseudomonas aeruginosa. Apmis, 128(3), 220-231. https://doi.org/10.1111/apm.13010

da Silva Baldivia, D., Ferreira Leite, D., Tsuyoshi Hiramatsu de Castro, D., Ferreira Campos, J., Pereira dos Santos, U., Julian Paredes-Gamero, E., Alexandre Carollo, C., Brentan Silva, D., de Picoli Souza, K., \& Lucas dos Santos, E. (2018). Evaluation of In Vitro Antioxidant and Anticancer Properties of the Aqueous Extract from the Stem Bark of Stryphnodendron adstringens. International Journal of Molecular Sciences Article. https://doi.org/10.3390/ijms19082432

de Freitas, A. L. D., Kaplum, V., Rossi, D. C. P., da Silva, L. B. R., Melhem, M. de S. C., Taborda, C. P., de Mello, J. C. P., Nakamura, C. V., \& Ishida, K. (2018). Proanthocyanidin polymeric tannins from Stryphnodendron adstringens are effective against Candida spp. isolates and for vaginal candidiasis treatment. Journal of Ethnopharmacology, 216, 184-190. https://doi.org/10.1016/j.jep.2018.01.008

De Oliveira, J. R., De Aguiar Almeida, R. B., Das Graças Figueiredo Vilela, P., De Oliveira, F. E., Da Rocha, R. F., Jorge, A. O. C., \& De Oliveira, L. D. (2014). Control of microorganisms of oral health interest with Arctium lappa L. (burdock) extract non-cytotoxic to cell culture of macrophages (RAW 264.7). Archives of Oral Biology, 59(8), 808-814. https://doi.org/10.1016/j.archoralbio.2014.05.013

de Oliveira, J. R., de Castro, V. C., Vilela, P. das G. F., Camargo, S. E. A., Carvalho, C. A. T., Jorge, A. O. C., \& de Oliv eira, L. D. (2013). Cytotoxicity of Brazilian plant extracts against oral microorganisms of interest to dentistry. BMC Complementary and Alternative Medicine, 13. https://doi.org/10.1186/14726882-13-208

de Oliveira, J. R., de Jesus, D., Figueira, L. W., de Oliveira, F. E., Pacheco Soares, C., Camargo, S. E. A., Jorge, A. O. C., \& de Oliveira, L. D. (2017). Biological activities of Rosmarinus officinalis L. (rosemary) extract as analyzed in microorganisms and cells. Experimental Biology and Medicine, 242(6), 625-634. https://doi.org/10.1177/1535370216688571

De Santana, B. F., Voeks, R. A., \& Funch, L. S. (2016). Ethnomedicinal survey of a maroon community in Brazil's Atlantic tropical forest. Journal of Ethnopharmacology, 181, 37-49. https://doi.org/10.1016/J.JEP.2016.01.014

Durovic, A., Eberhard, N., Schären, S., \& Widmer, A. F. (2020). Parvimonas micra as a rare cause of spondylodiscitis - Case series from a single centre. Swiss Medical Weekly, 150(25-26), 1-5. https://doi.org/10.4414/smw.2020.20272

Ferreira, S. B., Palmeira, J. D., Souza, J. H., Almeida, J. M., Figueiredo, M. C. P., Pequeno, A. S., Arruda, T. A. A. R. \& C. R. (2010). Evaluation of the antimicrobial activity in vitro of the hydroalcoholic extract Stryphnodendron adstringens against of Staphylococcus aureus strains. 42 (January), $27-31$.

Filho, P. R. do. S., Ferreira, L. A., \& Gouvêa, C. M. C. P. (2011). Protective action against chemical-induced genotoxicity and free radical scavenging activities of stryphnodendron adstringens ("barbatimão") leaf extracts. Revista Brasileira de Farmacognosia, 21(6), 1000-1005. https://doi.org/10.1590/S0102-695X2011005000176

Ganguly, S., \& Mitchell, A. P. (2011). Mucosal biofilms of Candida albicans. In Current Opinion in Microbiology (Vol. 14, Issue 4, pp. 380-385). Elsevier Current Trends. https://doi.org/10.1016/j.mib.2011.06.001

Graziano, T. S., Calil, C. M., Sartoratto, A., Franco, G. C. N., Groppo, F. C., \& Cogo-Müller, K. (2016). In vitro effects of Melaleuca alternifolia essential oil on growth and production of volatile sulphur compounds by oral bacteria. Journal of Applied Oral Science, 24(6), 582-589. https://doi.org/10.1590/1678775720160044

Headland, S. E., \& Norling, L. V. (2015). The resolution of inflammation: Principles and challenges. Seminars in Immunology, 27(3), 149-160. https://doi.org/10.1016/j.smim.2015.03.014

Henriques, B. O., Corrêa, O., Azevedo, E. P. C., Pádua, R. M., Oliveira, V. L. S. D., Oliveira, T. H. C., Boff, D., Dias, A. C. F., Souza, D. G. D., Amaral, F. A., Teixeira, M. M., Castilho, R. O., \& Braga, F. C. (2016). In Vitro TNF- $\alpha$ Inhibitory Activity of Brazilian Plants and Anti-Inflammatory Effect of Stryphnodendron adstringens in an Acute Arthritis Model. Evidence-Based Complementary and Alternative Medicine, 2016. https://doi.org/10.1155/2016/9872598

Hickl, J., Argyropoulou, A., Sakavitsi, M. E., Halabalaki, M., Al-Ahmad, A., Hellwig, E., Aligiannis, N., Skaltsounis, A. L., Wittmer, A., Vach, K., \& Karygianni, L. (2018). Mediterranean herb extracts inhibit microbial growth of representative oral microorganisms and biofilm formation of Streptococcus mutans. PLoS ONE, 13(12). https://doi.org/10.1371/journal.pone.0207574

Ishida, K., Palazzo de Mello, J. C., Garcia Cortez, D. A., Dias Filho, B. P., Ueda-Nakamura, T., \& Nakamura, C. V. (2006). Influence of tannins from Stryphnodendron adstringens on growth and virulence factors of Candida albicans. Journal of Antimicrobial Chemotherapy, 58(5), 942-949. 
https://doi.org/10.1093/jac/dk1377

Jin, Q., Lee, J. W., Jang, H., Choi, J. E., Lee, D., Hong, J. T., Kim, Y., Lee, M. K., \& Hwang, B. Y. (2016). Sesquiterpenes from Inula japonica with Inhibitory Effects on Nitric Oxide Production in Murine Macrophage RAW 264.7 Cells. Journal of Natural Products, 79(6), 1548-1553. https://doi.org/10.1021/acs.jnatprod.5b01106

Karched, M., Bhardwaj, R. G., Inbamani, A., \& Asikainen, S. (2015). Quantitation of biofilm and planktonic life forms of coexisting periodontal species. Anaerobe, 35, 13-20. https://doi.org/10.1016/j.anaerobe.2015.04.013

Karygianni, L., Cecere, M., Argyropoulou, A., Hellwig, E., Skaltsounis, A. L., Wittmer, A., Tchorz, J. P., \& Al-Ahmad, A. (2019). Compounds from Olea europaea and Pistacia lentiscus inhibit oral microbial growth. BMC Complementary and Alternative Medicine, 19(1), 1-10. https://doi.org/10.1186/s12906$019-2461-4$

Karygianni, L., Cecere, M., Skaltsounis, A. L., Argyropoulou, A., Hellwig, E., Aligiannis, N., Wittmer, A., \& Al-Ahmad, A. (2014). High-level antimicrobial efficacy of representative Mediterranean natural plant extracts against oral microorganisms. BioMed Research International, 2014. https://doi.org/10.1155/2014/839019

Krzyściak W, Jurczak A, Kościelniak D, Bystrowska B, S. A. (2014). The virulence of Streptococcus mutans and the ability to form biofilms. Eur J Clin Microbiol Infect Dis, 33(4), 499-515.

Lorenzi, H., \& Matos, F. J. A. (2002). Medicinal plants from Brazil: native and exotic. (Plantarum). Institute of Flora Studies.

Maroni, B. C. D. S. L. \& M. S. (2006). Medicinal plants from the Cerrado of Botucatu (illustrate). guide UNESP.

Mehraj, J., Witte, W., Akmatov, M. K., Layer, F., W. G. K. G. (2016). Epidemiology of Staphylococcus aureus Nasal Carriage Patterns in the Community. Curr Top Microbiol Immunol, 398, 55-87.

Okuda, T., Kokubu, E., Kawana, T., Saito, A., Okuda, K., \& Ishihara, K. (2012). Synergy in biofilm formation between Fusobacterium nucleatum and Prevotella species. Anaerobe, 18(1), 110-116. https://doi.org/10.1016/j.anaerobe.2011.09.003

Oliveira, J. R. de, de Jesus Viegas, D., Martins, A. P. R., Carvalho, C. A. T., Soares, C. P., Camargo, S. E. A., Jorge, A. O. C., \& de Oliveira, L. D. (2017). Thymus vulgaris L. extract has antimicrobial and anti-inflammatory effects in the absence of cytotoxicity and genotoxicity. Archives of Oral Biology, 82, 271279. https://doi.org/10.1016/j.archoralbio.2017.06.031

Onbas, R., Kazan, A., Nalbantsoy, A., \& Yesil-Celiktas, O. (2016). Cytotoxic and Nitric Oxide Inhibition Activities of Propolis Extract along with Microencapsulation by Complex Coacervation. Plant Foods for Human Nutrition, 71(3), 286-293. https://doi.org/10.1007/s11130-016-0558-1

Organization for Economic Co-operation and Development (OECD). (2014). Guidelines for Testing of Chemicals, Section 4: Health Effects, Test No. 487: In Vitro Mammalian Cell Micronucleus Test.

Pathan MM, B. K. \& J. V. (2017). Comparative evaluation of the efficacy of a herbal mouthwash and chlorhexidine mouthwash on select periodontal pathogens: An in vitro and ex vivo study. J Indian Soc Periodontol, 21(4), 270-275.

Pellenz, N. L., Barbisan, F., Azzolin, V. F., Duarte, T., Bolignon, A., Mastella, M. H., Teixeira, C. F., Ribeiro, E. E., Mânica Da Cruz, I. B., Duarte, M. M. M. F., \& Facchiano, F. (2018). Analysis of In Vitro Cyto-and Genotoxicity of Barbatimão Extract on Human Keratinocytes and Fibroblasts. https://doi.org/10.1155/2018/1942451

Pereira, E. M. R., Gomes, R. T., Freire, N. R., Aguiar, E. G., Brandão, M. D. G. L., \& Santos, V. R. (2011). In vitro antimicrobial activity of Brazilian medicinal plant extracts against pathogenic microorganisms of interest to dentistry. Planta Medica, 77(4), 401-404. https://doi.org/10.1055/s-0030-1250354

Pérez-Chaparro, P. J., McCulloch, J. A., Mamizuka, E. M., Moraes, A. da C. L., Faveri, M., Figueiredo, L. C., Duarte, P. M., \& Feres, M. (2018). Do different probing depths exhibit striking differences in microbial profiles? Journal of Clinical Periodontology, 45(1), 26-37. https://doi.org/10.1111/jcpe.12811

Pourhajibagher, M., Ghorbanzadeh, R., \& Bahador, A. (2017). Culture-dependent approaches to explore the prevalence of root canal pathogens from endodontic infections. Brazilian Oral Research, 31, e108. https://doi.org/10.1590/1807-3107bor-2017.vol31.0108

Razina, I. N., Chesnokova, M. G., \& Nedoseko, V. B. (2017). The relevance of Candida spp. in chronic periodontal disease. Stomatologiia, 96(4), 4-6. https://doi.org/10.17116/stomat20179644-6

Rôças, I. N., \& Siqueira, J. F. (2018). Frequency and levels of candidate endodontic pathogens in acute apical abscesses as compared to asymptomatic apical periodontitis. PLOS ONE, 13(1). https://doi.org/10.1371/journal.pone.0190469

Sabino, A. P. L., Eustáquio, L. M. S., Miranda, A. C. F., Biojone, C., Mariosa, T. N., \& Gouvêa, C. M. C. P. (2018). Stryphnodendron adstringens ("Barbatimão") Leaf Fraction: Chemical Characterization, Antioxidant Activity, and Cytotoxicity Towards Human Breast Cancer Cell Lines. Applied Biochemistry and Biotechnology, 184(4), 1375-1389. https://doi.org/10.1007/s12010-017-2632-z

Seo, Y. H., Jeon, J. H., Jeong, M., Ryu, S. M., Jeon, W. K., Jang, D. S., Shim, S. H., Lee, D., Choi, J. H., \& Lee, J. (2018). Chemical Constituents of Apios americana Tubers and Their Inhibitory Activities on Nitric Oxide Production in Lipopolysaccharide-Stimulated RAW 264.7 Macrophages. Journal of Natural Products, 81(7), 1598-1603. https://doi.org/10.1021/acs.jnatprod.8b00182

Silva-de-Andrade, L., Barros-de-Castro, D., \& Chen-Chen, L. (2006). Efeito Modulador do Extrato de Stryphnodendron adstringens Mart. BarbatimoContra Danos Induzidos pela Mitomicina C em Camundongos. Journal of the Brazilian Society of Ecotoxicology, 1(2), 127-130. https://doi.org/10.5132/jbse.2006.02.007

Takarada, K., Kimizuka, R., Takahashi, N., Honma, K., Okuda, K., \& Kato, T. (2004). A comparison of the antibacterial efficacies of essential oils against oral pathogens. Oral Microbiology and Immunology, 19(1), 61-64. https://doi.org/10.1046/j.0902-0055.2003.00111.x 
Research, Society and Development, v. 10, n. 11, e364101119953, 2021

(CC BY 4.0) | ISSN 2525-3409 | DOI: http://dx.doi.org/10.33448/rsd-v10i11.19953

Tamai, R., Sugamata, M., \& Kiyoura, Y. (2011). Candida albicans enhances invasion of human gingival epithelial cells and gingival fibroblasts by Porphyromonas gingivalis. Microbial Pathogenesis, 51(4), 250-254. https://doi.org/10.1016/j.micpath.2011.06.009

Tennert C, Fuhrmann M, Wittmer A, Karygianni L, Altenburger MJ, Pelz K, H. E. A.-A. A. (2014). New bacterial composition in primary and persistent/secondary endodontic infections with respect to clinical and radiographic findings. $J$ Endod, 40(5), 670-677.

van Duijvenbode, D. C., Kuiper, J. W. P., Holewijn, R. M., \& Stadhouder, A. (2018). Parvimonas micra Spondylodiscitis: A Case Report and Systematic Review of the Literature. Journal of Orthopaedic Case Reports, 8(5), 67-71. https://doi.org/10.13107/jocr.2250-0685.1216

Veloso, D. J., Abrão, F., Martins, C. H. G., Bronzato, J. D., Gomes, B. P. F. A., Higino, J. S., \& Sampaio, F. C. (2020). Potential antibacterial and antihalitosis activity of medicinal plants against oral bacteria. Archives of Oral Biology, 110, 104585. https://doi.org/10.1016/j.archoralbio.2019.104585

Vilar, J. B., D’Oliveira, M. I. P., Santos, S. da C., \& Chen, L. C. (2010). Cytotoxic and genotoxic investigation on barbatimão [Stryphnodendron adstringens (Mart.) Coville, 1910] extract. Brazilian Journal of Pharmaceutical Sciences, 46(4), 687-694. https://doi.org/10.1590/S1984-82502010000400010

Wilson, C. E., Cathro, P. C., Rogers, A. H., Briggs, N., \& Zilm, P. S. (2015). Clonal diversity in biofilm formation by Enterococcus faecalis in response to environmental stress associated with endodontic irrigants and medicaments. International Endodontic Journal, 48(3), 210-219. https://doi.org/10.1111/iej.12301 